\title{
Konsiliencja, czyli o porozumieniu między naukami w trzecim tysiącleciu
}

\author{
Elżbieta Chrzanowska-Kluczewska \\ Uniwersytet Jagielloński w Krakowie \\ elzbieta.chrzanowska-kluczewska@uj.edu.pl
}

\begin{abstract}
Streszczenie
Konsiliencja (termin wywodzacy się z logiki indukcyjnej a „,zmodernizowany” w latach 1990tych przez E. O. Wilsona, twórce socjobiologii) odnosi się do odwiecznego marzenia ludzkości o unifikacji wiedzy z wszelkich dziedzin - od nauk ścistych, poprzez nauki społeczno-ekonomiczne, aż do humanistyki a nawet sztuk wizualnych. Jest to poszukiwanie wspólnego systemu dla całokształtu wiedzy ludzkiej, oparte na wierze $w$ jedność natury $i$ uporzadkowanie świata. We współczesnej nauce znalazło odzwierciedlenie w Ogólnej Teorii Systemów, naukach hybrydycznych i studiach interdyscyplinarnych. Autorka dowodzi, że metodologiczne poszukiwania wspótczesnego językoznawstwa, które zajmuje miejsce centralne $w$ stosunku do wielu nauk, moga wskazać nam droge ku konsiliencji poprzez poszukiwanie kategorii o wielkiej ogólności (konieczność kontra przypadkowość, model matematyczny kontra model niematematyczny, struktura gry, itp.). Ostatecznie konsiliencja jest pytaniem o możliwość wypracowania wspólnego języka i wspólnej problematyki dla naukowców w obliczu postępującej wąskiej specjalizacji i szczegółowości w badaniach.
\end{abstract}

Słowa kluczowe: konsiliencja, struktura, teoria gier, konieczność a przypadek, taczenie przeciwieństw

Abstract

Consillience - Consensus Between Sciences in the Third Millenium/21 ${ }^{\text {st }}$ Century

Consilience (the term originating in inductive logic and "modernized" in the 1990s by E. O. Wilson, the creator of sociobiology) refers to the age-long dream of humanity that one day all branches of learning will see their unification - from the sciences, through social and economic studies, to humanities and even visual arts. Thus, consilience is a search for a common system that would underlie the totality of human knowledge, rooted in the belief in the unity of nature and orderliness of our universe. It has found its reflection in the General Systems Theory, hybrid disciplines and interdisciplinary studies. The author argues that the methodological quests of modern linguistics, which occupies a central position in relation to several disciplines, can direct us towards reaching consilience by focusing on categories and concepts of great generality (necessity vs. contingency, mathematical vs. non-mathematical modelling, the structure of game, etc.). Ultimately, consilience raises a question as to the 
feasibility of working out a common language and a common set of problems for all scholars and scientists despite the progressing narrowness of specialization and minuteness of research.

Keywords: consilience, structure, game theory, necessity vs. contingency, combination of opposites

\section{Wprowadzenie}

Słowo konsiliencja (konsyliencja) jest zapożyczeniem z języka angielskiego, gdzie funkcjonuje jako consilience. Nie jest to termin ogólnie w angielszczyźnie znany - twierdzi się, że pojawił się w r. 1840 w książce Williama Whewella The Philosophy of the Inductive Sciences. W logice indukcyjnej odnosi się do sytuacji, w której jeden zbiór praw indukcyjnych okazuje się zgodny z innym zbiorem o odrębnej derywacji, czyli - innymi słowy - gdy dochodzi do tej samej generalizacji z zupełnie odrębnych klas faktów. Termin ten został „zmodernizowany" w latach 90-tych XX wieku przez światowej sławy amerykańskiego uczonego Edwarda O. Wilsona, twórcę socjobiologii, który określa nim odwieczne marzenie ludzkości o jedności natury, uporządkowaniu świata i unifikacji wiedzy z wszelkich dziedzin - od nauk ścisłych, poprzez nauki społeczne i ekonomiczne, aż do humanistyki a nawet sztuk pięknych (artes). Wilson nazywa to marzenie ,jońskim zauroczeniem”, bowiem pojawiło się już u Talesa, by powracać cyklicznie w Renesansie, Oświeceniu i nauce współczesnej (idea unifikacji nie była obca Albertowi Einsteinowi, czynił też do niej aluzje Claude Lévi-Strauss).

To poszukiwanie wspólnego systemu dla całokształtu wiedzy ludzkiej znalazło też swój wyraz w tzw. Ogólnej Teorii Systemów, zaproponowanej w Chicago już w r. 1937, a wprowadzonej oficjalnie w latach 50-tych XX wieku i ponownie wracającej w orbitę zainteresowania współczesnej nauki. Ciekawe, że twórcą Teorii Systemów był również biolog, wiedeński uczony Ludwig von Bertalanffy, który w r. 1954 powołał do życia Towarzystwo do Badania Systemów, wraz z biomatematykiem A. Rapoportem, zajmującym się zastosowaniem teorii sieci w neurobiologii. Dołączyli do nich ekonomiści, lekarze, filozofowie, biochemicy, cybernetycy oraz twórcy teorii informacji i komunikacji (m. in. Norbert Wiener i Claude Shannon), wreszcie twórcy matematycznej teorii gier - John von Neumann i Oscar Morgenstern. W ich nadziei na odnalezienie cech wspólnych wszystkich systemów operujących wewnątrz ludzkiego organizmu, w grupach ludzkich i w świecie naturalnym pobrzmiewa odległy głos Gottfrieda W. Leibniza, a ściślej jego propozycji Mathesis Universalis - rachunku uniwersalnego, czy uniwersalnego zapisu wszelkich praw 
życia. Poszukiwanie wspólnego systemu dla wiedzy ludzkiej, a co za tym idzie uniwersalnego języka nauki, może nam się wydawać zbyt śmiałe, zbyt „metafizyczne” czy zbyt utopijne. Jest istotnie wizją odległą, ale ponieważ idea konsiliencji nie została jak dotąd sfalsyfikowana, zasługuje na chwilę refleksji.

Wilson (1998/2002) twierdzi, że najlepszą drogą ku osiągnięciu konsiliencji w przewidywalnej przyszłości jest powoływanie do życia tzw. hybrydycznych dziedzin wiedzy - sam zresztą z powodzeniem rozwinął socjobiologię, powstała też biomatematyka, bio- i socjofizyka, a osiągnięcia biochemii pozostają dziś poza wszelkimi wątpliwościami. O potrzebie tworzenia hybrydycznych dyscyplin świadczy również stale rosnące zainteresowanie studiami międzywydziałowymi. O ile jednak najłatwiej tworzyć takie hybrydy wewnątrz pewnych grup nauk (np. wewnątrz nauk ścisłych czy wewnątrz szeroko pojętej humanistyki), o wiele trudniejsze jest stworzenie hybryd na połączeniu nauk ścisłych i społecznych, a jeszcze gorzej wygląda to na złączu między naukami ścisłymi a humanistyką. Niektóre nazwy tych hybryd brzmią groteskowo lub dwuznacznie, by wspomnieć np. ekofeminizm.

\section{Konsiliencja a teorie języka}

Od tego momentu dyskusja nasza odbywać się będzie z perspektywy dyscypliny wiedzy przeze mnie reprezentowanej, ponieważ wydaje mi się, że językoznawstwo współczesne zajmuje interesującą pozycję wśród nauk. Filologie dawnego stylu, bliższe tradycyjnej humanistyce, przesunęły się w XX w. ku logice symbolicznej, głównie za sprawą filozofii analitycznej szkół amerykańskich i brytyjskich (generatywizm, gramatyki typu Montague czy semantyka oparta na teorii gier odegrały też niebagatelna rolę), by następnie - w obliczu pewnych nieprzekraczalnych barier metodologicznych - otworzyć się ku całej gamie nauk społecznych i kognitywnych. Językoznawstwo orientacji kognitywnej posiada z punktu widzenia konsiliencji niewątpliwe zasługi - dziś mówimy już pełnoprawnie o poetyce, stylistyce i retoryce kognitywnej czy o empirycznym wymiarze rezonansu czytelniczego, choć nadal na obrzeżach nauk kognitywnych powstają takie chimery jak artificial emotion (AE), wzorowana na artificial intelligence (AI) i mająca zajmować się cybernetycznym programowaniem emocji ludzkich, a której sama nazwa jest już oksymoronem.

Nie ulega kwestii, że współczesne językoznawstwo zwraca się w kierunku wielu gałęzi wiedzy, co czyni z niego naukę otwartą, plasującą się w dosyć centralnym punkcie, w takim locus, z którego jesteśmy uprawnieni, a nawet zobowiązani do zadawania pytań o 
konsiliencję. Sama zresztą od pewnego czasu uczestniczę w seminariach dla architektów i rzeźbiarzy, których interesują takie kategorie filozoficzne i językowe jak przestrzeń logiczna, światy możliwe, temporalność czy gra. Tak więc mam już swój maleńki osobisty wkład w przekraczanie barier pomiędzy dziedzinami wiedzy tradycyjnie nieuważanymi za pokrewne, choć zdaję sobie sprawę, że nie wszyscy twórcy sztuk wizualnych taką możliwość uznają, by zacytować słowa Marca Chagalla: „Osobiście nie wierzę, aby dążenia naukowe mogły być przydatne sztuce. Impresjonizm i kubizm są mi obce. Sztuka zdaje mi się być przede wszystkim stanem duszy".

Zagadnienie konsiliencji sprowadza się zasadniczo do pytania o istnienie struktury i o jej formę. Zajrzyjmy więc ponownie na pole współczesnej lingwistyki. Strukturalizm, zarówno europejski jak i amerykański, pomimo swych niewątpliwych, niepodważalnych zasług dla opisu języka ludzkiego, doprowadził strukturę do granic przyzwoitości. Generatywizm Noama Chomsky’ego okazał się również nadmiernie strukturalny. Osobiście zawsze uważałam Chomsky’ego za nietypowego kognitywistę (choć znacznie częściej określa się go mianem neoracjonalisty), który od lat konsekwentnie posługuje się aparatem matematycznologicznym. Z kolei tenże aparat badawczy dla większości zainteresowanych funkcjonowaniem języka ludzkiego wydaje się odstręczający, stąd tylu krytyków gramatyk transformacyjno-generatywnych.

Po osiągnięciu apogeum przez strukturalizm wahadło metodologiczne przechyliło się w druga stronę i przyszła krytyka ze strony postmodernizmu. Dobrze ujmuje ten początkowy zapał tytuł książki Umberto Eco La struttura assente (Nieobecna struktura). Wkrótce posypały się inne pomysły, ujmowane w formę sloganów:

Nie ma wielkich metanarracji, czyli metastruktur.

Nie ma struktury zamkniętej, jest nieskończoność.

Nie ma struktury głębokiej, istnieje tylko powierzchnia.

Nie ma trójwymiarowości, jest tylko spłaszczenie.

Nie ma hierarchii (np. dendrytów), wszystkie elementy są równowartościowe.

Nie ma autonomii i odrębności podmiotu od przedmiotu, jest pluralizm a dychotomie znikają.

Nie ma jasno zarysowanych kategorii - albo granice między nimi ulegają rozmyciu, albo też wagi nabierają przejścia i przestrzenie „pomiędzy’, np. „bramy” pomiędzy światami w fikcji.

Nie może już być mowy o oryginalności, istnieje tylko intertekstualność i eklektyzm. 
W miejsce struktur hierarchicznych, binarnych lub niebinarnych, Gilles Deleuze zaproponował układ rizomiczny - kłącze jako symbol poststrukturalnej organizacji. Kłącze jest acentryczne i ahierarchiczne, rozłazi się we wszystkich kierunkach, a każdy jego punkt można połączyć liniowo z innym punktem. Deleuze twierdził, że kłącze jest astrukturalne, jednak można z tą opinią polemizować. Jacques Derrida próbował z kolei zastąpić strukturę języka opartą na centrum grą, wyolbrzymiając w ten sposób niestabilność i przypadkowość systemu semiotycznego jakim jest język naturalny. Na temat ,przygodności” języka wypowiadał się też inny filozof postmoderny, Richard Rorty ([1986]1996).

Te dekonstrukcyjne postulaty zdecydowanie odrzuca Wilson. Istotnie, próba zastąpienia struktury niekończącą się grą, właściwie dowolnym igraniem elementów układu w żadnym razie nie może stanowić modelu dla nauk ścisłych - jest po prostu nazbyt destrukcyjna. Wilson (2002: 324), jak na przedstawiciela nauk biologicznych przystało, krytykuje derridiańskie pomysły jako „mgliste wytwory galijskiego esprit”, słusznie podejrzewając Derridę o ukrytą zabawę z czytelnikami jego tekstów. Skoro cały język jest polem gry, to i teksty Derridy odczytywać można jako kpinę z odbiorcy, a jednocześnie auto-demontaż. Broń dekonstrukcji zwraca się bowiem również przeciwko własnemu dyskursowi, który musi ostatecznie podważyć.

Po latach mody na dekonstrukcję wraca powoli moda na rekonstrukcję. Językoznawcy na szczęście w tej rekonstrukcji uczestniczyć nie muszą, ponieważ tak naprawdę niczego nie zdekonstruowali, a co najwyżej zastąpili np. model generatywny modelem kognitywnym. Jestem głęboko przekonana, że ,niewywracalny słoń strukturalizmu” jest i pozostanie w naszych badaniach na zawsze. Ostatecznie językoznawstwo jest po części nauką ścisłą, a więc nie może obejść się bez rozwiązań systemowych.

\section{3. 'Gra' jako przekraczanie 'struktury'}

Powróćmy jednak na chwilę do pojęcia „gry”. Niezaprzeczalnie zarówno Ludwig Wittgenstein jak i Derrida mieli sporo racji podkreślając „growy” charakter języka (amerykański strukturalista Charles Hockett porównywał również samo językoznawstwo do gry), choć nadali jej zbyt szerokie uprawnienia w języku. Warto jednak pamiętać, że gra (w przeciwieństwie do zabawy) również posiada swoistą strukturę. Dla naszych rozważań o konsiliencji najistotniejsza jest dwoista natura gry jako „przypadkowości” i „,konieczności”, warto bowiem popatrzeć na świat naturalny i na działalność w nim ludzi właśnie poprzez pryzmat przypadku i konieczności obecnych w każdym systemie i w każdej formie 
aktywności. Le hasard et la nécessité (Przypadek i konieczność) to tytuł książki francuskiego noblisty Jacquesa Monoda (1970) na tyle ważnej, by jego nazwisko znalazło się w tzw. Chicagowskim Kanonie Wielkich Książek Cywilizacji Zachodniej (lista ta cytowana jest w Europie Normana Daviesa - co ciekawe, wśród 153 nazwisk wielkich twórców cywilizacji europejskiej i amerykańskiej od starożytności po lata 80-te ubiegłego stulecia, jedno jest tylko polskie - Mikołaja Kopernika). Monod, lekarz, biochemik i genetyk napisał swój esej jako największą chyba pochwałę przypadku, występując przeciwko Einsteinowi, który miał rzekomo twierdzić, że „dobry Bóg nie gra w kości”. Monod uznaje przypadek za źródło wszelkiej nowości w biosferze. Czysty przypadek, wolność absolutna i ślepa, leży u korzeni ewolucji. Mutacje w sekwencjach DNA przebiegają na zasadzie absolutnej koincydencji i nie ma dla nich żadnego wytłumaczenia. Na poziomie molekularnym w proteinach wszystko jeśli chodzi o strukturę - sprowadza się do gry całkowicie ślepych kombinacji. Proteiny, a w konsekwencji życie na ziemi, ukazują nam też kompletną przypadkowość swojego powstania. W żadnym miejscu wywodu Monoda nie ma mowy o zewnętrznej przyczynie sprawczej. A jednak ten przypadek na poziomie DNA zostaje potem „zdyscyplinowany” przez mechanizm niezmienności i przekształcony w regułę, konieczność. Monod podkreśla więc, pomimo swej apologii przypadku, rolę konieczności w ewolucji ku coraz to wyższym formom życia. Wydaje mi się, że to bardzo istotne pytanie o stosunek, w jakim chaos i ład przeplatają się wzajemnie, można postawić w każdej dziedzinie wiedzy, i że odpowiedź na nie może rzucić światło na wspólny fundament rzeczywistości i naszej o niej wiedzy.

Przypatrując się różnym grom znajdziemy pośród nich takie, w których panuje wyłącznie przypadek, np. kości czy hazard typu ruletki (choć na obecnym poziomie wiedzy komputer może ułatwić obliczenie ustawienia się koła ruletki po obrocie, stąd zakaz wnoszenia notebooków do kasyn). Ale szachy, a może bardziej nawet backgammon (po polsku zwany tryktrakiem) to już gry, w których obserwujemy pokazowe wręcz połączenie chaosu i ładu, a więc bardzo swoistą strukturę, coś na kształt ewolucji Monoda. Pamiętajmy też, że chaos w kategoriach matematyczno-fizycznych nie do końca jest całkowicie chaotyczny i że istnieje w nim pewna doza determinacji, o czym świadczy matematyczna teoria chaosu (por. Stewart [1989]1994).

A co dzieje się na poziomie języka ludzkiego? O strukturze czyli konieczności w języku już mówiłam. Gdzie więc mamy szukać chaosu, poza nieskończoną semiozą Derridy, w którą osobiście nie wierzę? Niektórzy literaturoznawcy dopatrują się pochwały chaosu w pojęciu „karnawałowości” czy „polifonii” wywodzących się od Michaiła Bachtina. Inni zwracają uwagę na takie dzieła Jamesa Joyce'a jak Ulisses czy Finnegans Wake, których istotą jest 
właśnie chaos, rozsadzający tekst od środka. Ale joyce’olodzy wskazują też na misterną strukturę w obu dziełach (i proponują postać Aranżera w Ulissesie, por. Graff, 2002: 15), a więc na przypadek regulowany, przypadek ujęty w karby metody, konieczności. Owa oscylacja pomiędzy chaosem a harmonią widoczna jest we współczesnej kulturze, więc też bliska niepokojom wielu współczesnych twórców. B. S. Johnson (2002: 200-201), wcielając elementy chaosu do swojej dobrze jednak zaplanowanej literatury czy raczej liberatury, widzi w nim wytłumaczenie naszej rzeczywistości i cytuje Samuela Becketta, który marzył, aby „odnaleźć formę, co obejmuje sobą nieład”, słowem, aby „narzucić wzory Chaosowi”.

Powiedzenie Paula K. Feyrabenda „Anything goes” (,wszystko wolno”/ „wszystko ujdzie”/ „wszystko jest dopuszczalne”), które wydaje się być podsumowaniem natury chaosu w interpretacji wszelkich systemów znakowych człowieka, motto absolutnego relatywizmu i anarchizmu epistemologicznego, nie jest wcale hasłem udanym, ponieważ interpretacja posiada również swoje granice, o czym przekonywująco pisali Eco (1996) i Stanley Fish (2002). Również inne hasło Feyrabenda: ,przeciw metodzie” (tytuł jednej z jego książek: Against Method) jest zbyt anarchistyczne, choć Christopher Norris (2001), broniąc dobrej twarzy ponowoczesności, uważa je za błędnie przez czytelników zinterpretowane i niezgodne $\mathrm{z}$ intencją samego autora.

\section{Porządek kontra chaos w systemach naukowych}

Chaos ma swoje granice i znów powracamy do niewywracalnego słonia struktury, pytając o jej formę. W językoznawstwie oscylujemy nadal pomiędzy modelem matematycznym (algorytmicznym) lub logicznym (poszukując tzw. Formy Logicznej języka), a paradygmatem kognitywnym, mniej lub bardziej spsychologizowanym. Temu pierwszemu można zarzucić wiele, np. że pozostaje bez związku z rzeczywistością ludzką wraz z całą gamą jej zachowań nieracjonalnych i nieprzewidywalnych. Nie wiemy też, jakiego rzędu logikę można przyjąc do opisu języka naturalnego. Propozycje Richarda Montague czy Jaakko Hintikki, aby uciec się do logik wyższego rzędu jako adekwatnych do opisu modalności i kwantyfikacji w języku naturalnym są ekscytujące teoretycznie, ale groźne zarazem, ponieważ mogą doprowadzić nas do stworzenia takiego modelu, którego sami już nie potrafimy zinterpretować czy pojąć. Teoria względności i mechanika kwantowa dobitnie ukazały nam, iż umysł ludzki jest w stanie wygenerować takie modele, które są całkowicie niezrozumiałe dla naszej wyobraźni. A jednak pytanie o matematyczną (ewentualnie logiczną) budowę naszego wszechświata pozostaje nadal aktualne (pisali na ten temat Heller 
1992; Życiński 1992 i Mrozek 2002). Logika modalna określiła też konstrukty zwane „Światami możliwymi”, a właśnie w światach możliwych coraz liczniejsi filozofowie i fizycy-kosmolodzy upatrują kategorię integracyjną dla rozlicznych pól badawczych.

Modny dziś model kognitywny ma też wielu przeciwników. Psychologizm nieraz już był krytykowany w badaniach języka, przeciw psychologizmowi w krytyce literackiej opowiadał się m.in. Roman Ingarden ([1947] 2000), a sądzę, że gdyby przyjrzał się obecnie niektórym skrajnym metodom badawczym przyjętym przez teorię rezonansu czytelniczego, tylko utwierdziłby się w swoich przekonaniach. Cięższym zarzutem jest jednak opieranie modelu na domniemaniach co do przebiegu operacji kognitywnych, bowiem nadal wiemy zbyt mało o funkcjonowaniu mózgu i nadal uciekamy się do wygodnej, ale jakże subiektywnej introspekcji. Mimo to nauki kognitywne, poprzez swą otwartość na wszelkie aspekty ludzkiego Dasein - bycia-w-świecie, są niewątpliwym sprzymierzeńcem badaczy na drodze do konsiliencji.

Pragnę na koniec zasygnalizować jeszcze jeden problem. W gramatyce kognitywnej niezwykle interesujące okazało się pojęcie ,prototypu”, przejęte z psychologii, wraz z „modelem radialnym” kategorii. Połączono je jednak, na pewnym etapie adaptacji do opisu języka naturalnego, z Wittgensteinowską koncepcją ,podobieństwa rodzinnego”. To ostatnie, jak wiadomo ściśle związane z pojęciem gry, w gruncie rzeczy podważa i rozkłada istotę prototypu, który odwołuje się do wiązki cech. Family resemblance, oparte na efekcie domina, na przyległości tylko pojedynczych cech, okazuje się być koniem trojańskim semantyki prototypu (doskonale opisał to Kleiber [1990] 2003). Jednym słowem, podobieństwo rodzinne wnosi chaos do modelu radialnego kategorii.

Wspominam o tym, by podkreślić, do jakiego stopnia struktura gier może okazać się pouczająca i wiele mówiąca o budowie języka i świata. Gra jest w mojej opinii (por. Chrzanowska-Kluczewska 2004) kategorią strukturalną, funkcjonalną, a nawet ontologiczną, ważną dla badań skierowanych ku konsiliencji. Kilka lat temu (w r. 1997) komputer „Deep Blue” wreszcie wygrał partię szachów z Garry Kasparovem dzięki przeprogramowaniu go w ten sposób, by zawierał strategię częściowo podstępną. Dziś twierdzi się, że przyszłością może być mutowanie losowe w programie komputera, słowem le hasard Monoda włączony do programu informatycznego.

Jak długo konsiliencja nie zostanie podważona, możemy w nią wierzyć, choć jest ona niewątpliwie trudna do osiągnięcia, ponieważ różne dziedziny wiedzy zbyt są odrębne na szczegółowym poziomie opisu. Warto jednak zastanowić się czasem nad kategoriami o wielkiej ogólności, takimi jak np. porządek - ład - konieczność kontra chaos - przypadek, 
które mogą leżeć u podstaw każdego systemu i każdej metodologii badawczej (por. Lema Filozofię przypadku w zastosowaniu do badań literackich).

Posługując się na koniec porównaniem zaczerpniętym z teorii hiperprzestrzeni i światów równoległych, wedle której mogą istnieć paralelnie do siebie światy nic o sobie nie wiedzące i pozbawione możliwości komunikacji (o ile nagle nie otworzy się pomiędzy nimi tunel), współcześni naukowcy z odległych dziedzin, jeżeli nie uczynią wysiłku, by wyjść ze swego uniwersum, będą jak owe światy równoległe lub samotne monady Leibniza, zamknięte we własnej hermetycznej skorupie. W opinii amerykańskiego fizyka Michio Kaku (1994), na szczęście nie jest modny dziś typ uczonego w obdartym swetrze i całkowicie niekomunikatywnego - naukowiec powinien być dobrze ubranym erudytą i światowcem, zwracającym swe ucho ku językowi kolegów z innych, odległych dziedzin, z innych wszechświatów równoległych.

\section{Źródło}

Niniejszy artykuł stanowi przedruk z: Chrzanowska-Kluczewska, Elżbieta (2007) "Konsiliencja, czyli o porozumieniu między naukami w trzecim tysiącleciu”. [W:] (red.) Grzegorz Szpila, Język polski XXI wieku: analizy, oceny, perspektywy. Język a komunikacja 17. Kraków: Tertium; 15-23.

\section{Bibliografia}

Bertalanffy, Ludwig, von (1984) Ogólna teoria systemów. Podstawy, rozwój, zastosowania. Warszawa: PIW.

Chrzanowska-Kluczewska, Elżbieta (2004) Language-Games: Pro and Against. Kraków: Universitas.

Deleuze, Gilles, Félix Guattari (1980/1988) „Kłącze”. [W:] Colloquia Communia, 1-3 /36-38 / 1988: $221-237$.

Eco, Umberto ([1968] 1996) Nieobecna struktura. [La struttura assente] (tłum. Adam

Weinsberg i Paweł Bravo). Warszawa: Wydawnictwo KR.

Eco, Umberto, Richard Rorty, Jonathan Culler, Christine Brooke-Rose ([1992]1996) Interpretacja i nadinterpretacja. Kraków: Wydawnictwo Znak.

Feyrabend, Paul K. ([1975] 1996) Przeciw metodzie (tłum.) Stefan Wiertlewski. Wrocław: Siedmioróg.

Fish, Stanley ([1980] 1990/2002) Interpretacja, retoryka, polityka. Kraków: Universitas. 
Fleischer, Michael (2002) „System biologiczny, społeczny i kulturowy w ujęciu systemowej teorii kultury". [W:] Janusz Jaskóła, Anna Olejarczyk (red.) Kosmologie światów możliwych. Wrocław: Wydawnictwo Uniwersytetu Wrocławskiego; 157-190.

Graff, Agnieszka (2002) „Nie oddamy Joyce’a!”. [W:] Katarzyna Bazarnik (red.) Od Joyce’a do liberatury. Kraków: Universitas; 3- 20.

Heller, Michał (1992) „Co to znaczy, że przyroda jest matematyczna”. [W:] Michał Heller, Józef Życiński, Alicja Michalik (red.) Matematyczność przyrody. Kraków: OBI. Kraków; $9-22$.

Ingarden, Roman ([1947] 2000) Szkice z filozofii literatury. Kraków: Wydawnictwo Znak.

Johnson, Bryan Stanley (2002) „Czy ty nie za wcześnie piszesz wspomnienia?”. [W:] Katarzyna Bazarnik (red.) Od Joyce'a do liberatury. Kraków: Universitas; 195-214.

Kaku, Michio (1994) Hiperprzestrzeń. Wszechświaty równolegte, pętle czasowe i dziesiaty wymiar. Warszawa: Prószyński i S-ka.

Kleiber, Georges ([1990] 2003) Semantyka prototypu. Kategorie i znaczenie leksykalne. (tłum. Bronisława Ligara). Kraków: Universitas.

Lem, Stanisław ([1968] 2002) Filozofia przypadku. Literatura w świetle empirii. Kraków: Wydawnictwo Literackie.

Monod, Jacques ([1970] 1979) Przypadek i konieczność: esej o filozofii biologii współczesnej. Warszawa: Głos.

Mrozek, Jarosław (2002) „Idea świata niematematycznego jako forma eksplikacji tezy o matematyczności przyrody". [W:] Janusz Jaskóła, Anna Olejarczyk (red.) Kosmologie światów możliwych. Wrocław: Wydawnictwo Uniwersytetu Wrocławskiego; 73-81.

Norris, Christopher (2001) Dekonstrukcja przeciw postmodernizmowi. Teoria krytyczna i prawo rozumu. Kraków: Universitas.

Rorty, Richard ([1986] 1996), „Przygodność języka”. [W:] Stanisław Czerniak, Andrzej Szahaj (red.) Postmodernizm a filozofia. Wybór tekstów. Warszawa: Instytut Filozofii i Socjologii PAN; $113-142$.

Stewart, Ian ([1989] 1994) Czy Bóg gra w kości? Nowa matematyka chaosu. Warszawa: PWN.

Wilson, Edward O. ([1998] 2002) Konsiliencja. Jedność wiedzy, (tłum.) Jarosław Mikos. Poznań: Zysk i S-ka.

Życiński, Józef (1992) „Jak rozumieć matematyczność przyrody”. [W:] Michał Heller, Józef Życiński, Alicja Michalik (red.) Matematyczność przyrody. Kraków: OBI; $23-42$. 